\title{
Effects of Sponge-Derived Alkaloids on Activities of the Bacterial $\alpha$-D-Galactosidase and Human Cancer Cell $\alpha$-N-Acetylgalactosaminidase
}

\author{
Natalia Utkina (D), Galina Likhatskaya (D), Olesya Malyarenko (D), Svetlana Ermakova, Larisa Balabanova, \\ Lubov Slepchenko and Irina Bakunina*
}

check for

updates

Citation: Utkina, N.; Likhatskaya, G.; Malyarenko, O.; Ermakova, S.; Balabanova, L.; Slepchenko, L.; Bakunina, I. Effects of Sponge-Derived Alkaloids on Activities of the Bacterial $\alpha$-D-Galactosidase and Human Cancer Cell $\alpha-\mathrm{N}$-Acetylgalactosaminidase. Biomedicines 2021, 9, 510. https:// doi.org/10.3390/biomedicines 9050510

Academic Editor: Jun Lu

Received: 20 April 2021

Accepted: 2 May 2021

Published: 5 May 2021

Publisher's Note: MDPI stays neutral with regard to jurisdictional claims in published maps and institutional affiliations.

Copyright: (c) 2021 by the authors. Licensee MDPI, Basel, Switzerland. This article is an open access article distributed under the terms and conditions of the Creative Commons Attribution (CC BY) license (https:/ / creativecommons.org/licenses/by/ $4.0 /)$.
G.B. Elyakov Pacific Institute of Bioorganic Chemistry, Far Eastern Branch, Russian Academy of Sciences, Vladivostok 690022, Russia; utkinan@mail.ru (N.U.); galin56@mail.ru (G.L.); vishchuk@mail.ru (O.M.); swetlana_e@mail.ru (S.E.); lbalabanova@mail.ru (L.B.); lubov99d@mail.ru (L.S.)

* Correspondence: bakun@list.ru; Tel.: +7-(432)-231-07-05-(3); Fax: +7-(432)-231-07-05-(7)

\begin{abstract}
During a search for glycosidase inhibitors among marine natural products, we applied an integrated in vitro and in silico approach to evaluate the potency of some aaptamines and makaluvamines isolated from marine sponges on the hydrolyzing activity of $\alpha$-N-acetylgalactosaminidase ( $\alpha$-NaGalase) from human cancer cells and the recombinant $\alpha$-D-galactosidase ( $\alpha$-PsGal) from a marine bacterium Pseudoalteromonas sp. KMM 701. These alkaloids showed no direct inhibitory effect on the cancer $\alpha-\mathrm{NaGalase}$; but isoaaptamine (2), 9-demethylaaptamine (3), damirone B (6), and makaluvamine $\mathrm{H}(7)$ reduced the expression of the enzyme in the human colorectal adenocarcinoma cell line DLD-1 at $5 \mu \mathrm{M}$. Isoaaptamine (2), 9-demethylaaptamine (3), makaluvamine G (6), and zyzzyanone A (7) are slow-binding irreversible inhibitors of the bacterial $\alpha$-PsGal with the inactivation rate constants $\left(k_{\text {inact }}\right) 0.12 \mathrm{~min}^{-1}, 0.092 \mathrm{~min}^{-1}, 0.079 \mathrm{~min}^{-1}$, and $0.037 \mathrm{~min}^{-1}$, as well as equilibrium inhibition constants $\left(K_{i}\right) 2.70 \mu \mathrm{M}, 300 \mu \mathrm{M}, 411 \mu \mathrm{M}$, and $105 \mu \mathrm{M}$, respectively. Docking analysis revealed that these alkaloids bind in a pocket close to the catalytic amino acid residues Asp451 and Asp516 and form complexes, due to $\pi-\pi$ interactions with the Trp308 residue and hydrogen bonds with the Lys449 residue. None of the studied alkaloids formed complexes with the active site of the human $\alpha-\mathrm{NaGalase}$.
\end{abstract}

Keywords: marine sponges; aaptamines; makaluvamines; slow-binding irreversible inhibitors; bacterial $\alpha$-D-galactosidase; cancer $\alpha$-N-acetylgalactosaminidase

\section{Introduction}

Marine organisms, in particular marine sponges, are inexhaustible source of metabolites with various biological activities. A large group of secondary metabolites isolated from marine sponges are alkaloids [1]. Marine sponges of the genera Latrunculia, Batzella, Prianos, Zyzzya are a rich source of alkaloids bearing a pyrrolo[4,3,2-de]quinoline skeleton [2]. Pyrroloquinoline alkaloids have shown a variety of biological activities, including antifungal and antimicrobial [3], antioxidant [4], antimalarial activity [5]; inhibition of the HIF-1 $\alpha$ / p300 interaction [6]. Some makaluvamines demonstrated in vitro and in vivo cytotoxicity against various types of cancer $[7,8]$, which was attributed to the inhibition of topoisomerase II [9]. It is shown that numerous pyrroloiminoquinone alkaloids, including synthetic analogues, are active, their mechanisms of action, pharmacological properties, and safety have shown that they have great potential for creating new anticancer drugs [10].

The next interesting small group of biologically active marine alkaloids having a rare $1 H$-benzo[de]-1,6-naphthyridine skeleton are aaptamines [11]. Aaptamines have been isolated from marine sponges mainly of the genus Aaptos. All these compounds have either an N-methylated or a non-N-methylated 1,6-naphthyridine core fused with a functionalized benzenoid unit. Some of aaptamines have been reported to have $\alpha$-adrenoceptor 
blocking [12], anti-HIV-1 [13,14], antimycobacterial [13-15], antiherpes [16], and anticancer activity [17]. Aaptamine and its congeners were shown to act as inhibitors of different enzymes. They inhibit sortase A [18], monoamine oxidase [19], $\beta$-1,3-glucanase of marine mollusks [20], and showed proteasomal inhibitory activity [21].

In the last years, marine organisms have received increased attention as a source of enzyme inhibitors, due to their potential use in pharmacology [22]. Enzyme inhibitory activity is often found in sponge metabolites, among which kinase inhibitors are the most representative class of isolated inhibitors [23]. Glycosidase-catalyzed carbohydrate hydrolysis is a biologically widespread process. An imbalance in glycosidase functions has been considered one of the causes of some diseases, including cancer, viral infections, and metabolic and genetic disorders [24-28]. However, relatively few attempts have been made to find inhibitors of glycoside hydrolases, such as $\alpha$-D-galactosidases ( $\alpha$-D-galactoside galacto hydrolases, EC 3.2.1.22) and $\alpha-\mathrm{N}$-acetylgalactosaminidases (EC 3.2.1.49) among huge number of structurally unique low molecular marine natural products.

The enzyme $\alpha$-D-galactosidase from the cold-adaptable marine bacterium Pseudoalteromonas sp. KMM 701 is a typical exo-glycosidase that cleaves the $\alpha$-D-galactopyranos residues from the nonreducing end of various oligosaccharides including $\alpha-1,3$-bound galactose residues of glycoprotein of group substance of red blood B-cells [29]. It belongs to the 36 family of glycoside hydrolases $(\mathrm{GH})$ and has research interests, due to various possible fields of application, such as blood transfusion, infection diseases, structural studies in glycobiology $[30,31]$. $\alpha$-N-Acetylgalactosaminidase, which removes terminal $\alpha$-linked residues of $\mathrm{N}$-acetylgalactosaminide, is widespread in organs and tissues of mammals, bacteria, and fungi, is produced by all cancer cells and accumulated in the blood plasma of cancer patients, leading to immunosuppression in patients with advanced cancer [32,33]. Cancer $\alpha-\mathrm{NaGalase}$ belongs to the GH27 family. The level of enzyme activity and number its forms increase in blood serum, especially at the initial stage of the disease and the stage of metastasis [34]. Thus, $\alpha-\mathrm{N}$-acetylgalactosaminidase, being an immunosuppressive agent in cancer patients, is considered as a potential therapeutic target in cancer treatment.

It is known that glycosidase inhibitors can regulate or block the enzyme imbalance [24]. Therefore, the identification of potential inhibitors of both $\alpha-\mathrm{N}$-acetylgalactosaminidase and $\alpha$-D-galactosidase and their mode of action is of importance. Galacto-iteamine, unnatural analog of alkaloid iteamine (o-aminobenzyl $\beta$-D-glucopyranoside) isolated from Itea virginica L. inflorescence was the weak direct inhibitor of chicken liver $\alpha-\mathrm{N}$ acetylgalactosaminidase [35]. It was shown that the iminosugar DGJNAc can inhibit, stabilize, and chaperone human $\alpha$-NAGAL both in vitro and in vivo [36], but fucoidan from Fucus evanescens did not inhibit free $\alpha$-NaGalase, however, it reduced the expression of the enzyme in the DLD-1 cells [37]. The previously characterized low molecular inhibitors of the $\alpha$-D-galactosidase from marine sources are polyhydroxynaphthoquinone pigments from sea urchins and their synthetic analogues [38], polybrominated diphenyl ether and dibenzo- $p$-dioxins from Dysidea sponges [39] and pentacyclic guanidine alkaloids from the sponge Monanchora pulchra [40].

The main goal of this study was to evaluate in vitro alkaloids aaptamine (1), isoaaptamine (2), 9-demethylaaptamine (3), aaptanone (4), damirones A (5) and B (6), makaluvamines $H(7)$ and $G(8)$, and zyzzyanone $A(9)$ isolated from marine sponges as direct or indirect inhibitors of $\alpha$-N-acetylgalactosaminidase ( $\alpha$-NaGalase) from human cancer cells. Herein, evolutionarily related glycoside hydrolase $\alpha$-D-galactosidase from the marine bacterium Pseudoalteromonas sp. KMM 701 was used in addition to compare their enzyme inhibitory potential, and explore their possible way of interacting with enzymes through kinetic and molecular docking studies.

\section{Materials and Methods}

\subsection{Materials and Reagents}

Roswell Park Memorial Institute Medium (RPMI 1640), phosphate buffered saline (PBS), L-glutamine, penicillin-streptomycin solution, trypsine and fetal bovine serum (FBS), 
sodium hydrocarbonate $\left(\mathrm{NaHCO}_{3}\right)$, and agar were purchased from BioloT (Bolshoy Sampsonievsky avenue, Saint-Petersburg, Russia), p-nitrophenyl-N-acetyl- $\alpha$-D-galactosaminide (p-NPNA- $\alpha$-Gal), p-nitrophenyl- $\alpha$-D-galactopyranoside (pNP- $\alpha$-Gal), and Bradford reagent were purchased from Sigma-Aldrich (St. Louis, MO, USA); recombinant protein markers SDS-PAGE-electrophoresis, from BioRad (1000 Alfred Nobel Drive, Hercules, CA, USA). Silica gel (Sorbpolymer, Krasnodar, Russia), Sephadex LH-20 (Pharmacia Fine Chemicals), Polyamide (Woelm, Germany), and Polychrom-1 (powdered Teflon, Biolar, Olaine, Latvia) were used for column chromatography, Sorbfil plates coated with silica gel F254 (Sorbpolymer, Krasnodar, Russia) were used for TLC.

\subsection{Experimental Equipment}

Microplate spectrophotometer (BioTek Instruments, Highland Park, Winooski, VT, USA) was used for measuring of optical density at $400 \mathrm{~nm}$ (D400). Ultrasonic homogenizer Bandelin Sonopuls (Bandelin electronic GmbH \& Co., KG Heinrichstraße 3-4 12, 207, Berlin, Germany) was used for homogenization. GenBAflex-tubes 6-8 kDa (Scienova $\mathrm{GmbH}$, Wildenbruchstabe 1507745 Jena, Germany) were used for dialysis. 1H NMR and 13C NMR spectra were recorded on a Bruker AVANCE DRX-500 NMR spectrometer at 500 and $125 \mathrm{MHz}$, respectively. High-resolution electron ionization mass spectrometry (HREI MS) and high-resolution fast atom bombardment mass spectrometry (HRFAB MS) were performed on an AMD-604 S mass spectrometer (Intectra, Germany).

\subsection{Collection and Identification of Sponge Material}

We used freeze-dried samples of sponges A. aaptos (O45-113) and Z. fuliginosa (O9407), collected during scientific cruises of R/V Academik Oparin, which are kept in the collection of G.B. Elyakov Pacific Institute of Bioorganic Chemistry, Far Eastern Branch, Russian Academy of Sciences. The sponge A. aaptos was collected at Tho Chu Island $\left(9^{\circ} 18.5^{\prime}\right.$ N 103 29.6 E, at a depth of 6 m), South China Sea, Vietnam, in May 2013 during the 45th scientific cruise of R/V Academik Oparin. The sponge Z. fuliginosa was collected at Mid Islet $\left(16^{\circ} 14^{\prime} \mathrm{S} 149^{\circ} 59^{\prime} \mathrm{E}\right.$, at a depth of $\left.10 \mathrm{~m}\right)$, Eastern Australia, in July 1989 during the 9th scientific cruise of R/V Academik Oparin. Sponge samples were freeze-dried and stored in a refrigerator until used. The sponges were taxonomically identified by Dr. Vladimir B. Krasokhin.

\subsection{Isolation and Purification of Compounds}

A freeze-dried sample of the sponge A. aaptos $(20 \mathrm{~g})$ was extracted exhaustively with acetone, followed by EtOH. The acetone extract was chromatographed on a silica gel column in $\mathrm{CHCl}_{3}-\mathrm{EtOH}(3: 2)$ to obtain aaptamine $(\mathbf{1} ; 6 \mathrm{mg}$, yield $0.03 \%$ on dry weight of sponge), isoaaptamine (2;3.8 $\mathrm{mg}$, yield $0.019 \%)$, and 9-demethylaaptamine $(3 ; 3.5 \mathrm{mg}$, yield $0.017 \%$ ) after purification on a Sephadex $\mathrm{LH}-20$ column in $\mathrm{CHCl}_{3}-\mathrm{EtOH}(3: 1)$. The EtOH extract was concentrated and chromatographed on a Polyamide column with EtOH to give aaptanone (4; $3 \mathrm{mg}$, yield $0.015 \%$ ), final purification was achieved on a Sephadex LH-20 column using 50\% aqueous EtOH. Compounds 1-4 were identified by comparison of their spectroscopic data with those reported earlier [12,14,41,42], respectively.

Aaptamine (1): HREI MS m/z $229.0973[\mathrm{M}+\mathrm{H}]^{+}$, (calcd. for $\mathrm{C}_{13} \mathrm{H}_{13} \mathrm{~N}_{2} \mathrm{O}_{2}:$ 229.0977);

Isoaaptamine (2): HREI MS m/z $229.0971[\mathrm{M}+\mathrm{H}]^{+}$, (calcd. for $\mathrm{C}_{13} \mathrm{H}_{13} \mathrm{~N}_{2} \mathrm{O}_{2}:$ 229.0977); 9-demethylaaptamine (3): HREI MS $m / z 215.0817[\mathrm{M}+\mathrm{H}]^{+}$, (calcd. for $\mathrm{C}_{12} \mathrm{H}_{11} \mathrm{~N}_{2} \mathrm{O}_{2}: 215.0820$ );

Aaptanone (4): HRFAB MS m/z 281.0541 [M+Na] ${ }^{+}$, (calcd. for $\mathrm{C}_{13} \mathrm{H}_{10} \mathrm{~N}_{2} \mathrm{O}_{4} \mathrm{Na}$ : 281.0538).

A freeze-dried sample of the sponge Z. fuliginosa $(50 \mathrm{~g})$ was extracted with $50 \% \mathrm{EtOH}$ at room temperature; the solvent was concentrated to yield a dark red residue. This residue was triturated with $\mathrm{CHCl}_{3}$ to obtain the $\mathrm{CHCl}_{3}$-solubles, which were chromatographed on a Sephadex LH-20 column in $\mathrm{CHCl}_{3}$ to obtain damirones A $(5 ; 22 \mathrm{mg}$, yield $0.044 \%)$ and B (6; $18 \mathrm{mg}$, yield $0.036 \%$ ). $\mathrm{A} \mathrm{CHCl}_{3}$-insoluble solid was subjected to column chromatography on a Polychrome- 1 column with a solvent elution gradient from $\mathrm{H}_{2} \mathrm{O}$ to EtOH. Dark red fractions $(25-40 \%$ EtOH) were concentrated and chromatographed on a Sephadex LH-20 
column in $\mathrm{CHCl}_{3}$-EtOH-TFA (4:1:0.1\%) to obtain makaluvamine $\mathrm{H}$ (7; $8.5 \mathrm{mg}$, yield $0.017 \%$ ). A brownish-green fraction $(50 \% \mathrm{EtOH})$ was repeatedly chromatographed on a Sephadex LH-20 column in $\mathrm{CHCl}_{3}$-EtOH-TFA (3:1:0.1\%) to obtain makaluvamine $\mathrm{G}(\mathbf{8} ; 27.5 \mathrm{mg}$, yield $0.055 \%)$ and zyzzyanone A $(\mathbf{9} ; 3 \mathrm{mg}$, yield $0.006 \%)$. Compounds $5-9$ were identified by comparison of their spectroscopic data with those described earlier [43-46], respectively.

Damirone A (5): HREI MS m/z 216.0895 [M] $]^{+}$, (calcd. for $\mathrm{C}_{12} \mathrm{H}_{12} \mathrm{~N}_{2} \mathrm{O}_{2}$ : 216.0899);

Damirone B (6): HREI MS m/z 202.0739 [M] ${ }^{+}$, (calcd. forC $\mathrm{C}_{11} \mathrm{H}_{10} \mathrm{~N}_{2} \mathrm{O}_{2}: 202.0742$ );

Makaluvamine $\mathrm{H}$ (7): HREI MS $m / z$ 217.1211[M+H] $]^{+}$, (calcd. for $\mathrm{C}_{12} \mathrm{H}_{15} \mathrm{~N}_{3} \mathrm{O}: 217.1215$ ),

Makaluvamine G (8): HREI MS m/z $334.1550[\mathrm{M}+\mathrm{H}]^{+}$, (calcd. for $\mathrm{C}_{20} \mathrm{H}_{20} \mathrm{~N}_{3} \mathrm{O}_{2}: 334.1555$ ),

Zyzzyanone A (9): HRFAB MS m/z $350.1500[\mathrm{M}+\mathrm{H}]^{+}$, (calcd. for $\mathrm{C}_{20} \mathrm{H}_{20} \mathrm{~N}_{3} \mathrm{O}_{3}: 350.1504$ ).

\subsection{Cell Cultured}

Cancer cells RPMI-7951 (ATCC ${ }^{\circledR}$ no. HTB-66 ${ }^{\mathrm{TM}}$ ), MDA-MB-231 (ATCC ${ }^{\circledR}$ no.HTB-26 ${ }^{\mathrm{TM}}$ ), DLD-1 (ATCC ${ }^{\circledR}$ no.CCL-221), HT-29 (ATCC ${ }^{\circledR}$ no.HTB-38 ${ }^{\mathrm{TM}}$ ), HCT-116 (ATCC ${ }^{\circledR}$ no.CCL247), SK-MEL-5 (ATCC ${ }^{\circledR}$ no.HTB-70 ${ }^{\mathrm{TM}}$ ), and mouse healthy epidermal cells JB6 Cl41 (ATCC ${ }^{\circledR}$ no. CRL-2010 ${ }^{\mathrm{TM}}$ ) were obtained from the American Type Culture Collection (Manassas, VA, USA). Cells were cultured in appropriate culture medium supplemented with $10 \%$ FBS and $1 \%$ penicillin-streptomycin solution. The cell cultures were maintained at $37^{\circ} \mathrm{C}$ in humidified atmosphere containing $5 \% \mathrm{CO}_{2}$. For pretreatments with alkaloids human colorectal adenocarcinoma cell line DLD-1 was cultured in the same RPMI-1640 medium supplemented with $10 \%$ fetal bovine serum (FBS) and penicillin-streptomycin solution. Cells were maintained in a sterile environment and kept in an incubator at $5 \%$ $\mathrm{CO}_{2}$ and $37^{\circ} \mathrm{C}$ to promote growth. DLD- 1 cells were sub-cultured every 3-4 days by their rinsing with phosphate-buffered saline (PBS), adding trypsin to detach the cells from the tissue culture flask, and transferring $10-20 \%$ of the harvested cells to a new flask containing fresh growth media.

\subsection{Cytotoxic Activity Assays}

DLD- 1 cells $\left(8 \times 10^{3} / 200 \mu \mathrm{L}\right)$ were seeded in 96-well plates for $24 \mathrm{~h}$ at $37^{\circ} \mathrm{C}$ in a $5 \% \mathrm{CO}_{2}$ incubator. The cells were treated with compounds 1-9 at concentrations ranging from 0 to $20 \mu \mathrm{M}$ for an additional $24 \mathrm{~h}$. Subsequently, cells were incubated with 15 $\mu \mathrm{L}$ MTS (3-(4,5-dimethylthiazol-2-yl)-5-(3-carboxymethoxyphenyl)-2-(4-sulfophenyl)-2Htetrazolium) reagent for $3 \mathrm{~h}$, and the absorbance in each well was measured at $490 / 630 \mathrm{~nm}$ using a microplate reader "Power Wave XS" (Bio Tek, Winooski, VT, USA). All the experiments were repeated three times, and the mean absorbance values were calculated. The results are expressed in absorbance by the compound's treatment compared to the non-treated cells (control 1) and the compounds in medium (control 2). All the experiments were made in triplicate.

\subsection{Cell Treatment with Alkoloids}

DLD-1cells $\left(5.0 \times 10^{5}\right)$ were seeded in $6 \mathrm{~mm}$ dishes for $24 \mathrm{~h}$ at $37^{\circ} \mathrm{C}$ in a $5 \% \mathrm{CO}_{2}$ incubator. Then the cells were treated with compounds 1-9 at concentrations ranging from 0 to $20 \mu \mathrm{M}$ for an additional $24 \mathrm{~h}$. Then the cells were harvested using $0.02 \%$ EDTA, after this $3 \mathrm{~mL}$ of cold $15 \mathrm{mM}$ Tris- $\mathrm{HCl}(\mathrm{pH} 7.0)$ was added.

\subsection{Preparation of Cell Lysate}

Every 3-4 days cells were rinsed in phosphate buffered PBS, detached from the tissue culture flask by $1 \times$ trypsin/EDTA solution, harvested with RPMI-1640 medium and centrifuge at $500 \mathrm{rpm}$ for $3 \mathrm{~min}$. The culture media was discarded and cells pellet was resuspended in EDTA/Tris solution and frozen at $-80^{\circ} \mathrm{C}$.

\subsection{Isolation and Purification of $\alpha-N$-Acetylgalactosaminidase from Cell Lysates}

Frozen lysates of cancer cells in the $15 \mathrm{mM}$ Tris buffer, $\mathrm{pH} 7.0$ containing $0.02 \%$ EDTA, defrosted and sonicated 10 times during 1 min with a break of $1 \mathrm{~min}$. To remove the 
cellular detritus, the cell homogenate was centrifuged at $4{ }^{\circ} \mathrm{C}, 10,000 \mathrm{rpm}, 30 \mathrm{~min}$. The supernatant proteins were precipitated with 35\% ammonium sulfate, kept during four hours at $4{ }^{\circ} \mathrm{C}$ to form a pellet. The protein pellet was collected by centrifugation $\left(4{ }^{\circ} \mathrm{C}\right.$, $10,000 \mathrm{rpm}, 30 \mathrm{~min}$ ) and dissolved in $0.05 \mathrm{M}$ sodium citrate buffer, $\mathrm{pH}$ 5.0. The supernatant proteins were precipitated with $75 \%$ ammonium sulfate, kept overnight at $4{ }^{\circ} \mathrm{C}$ to form a pellet. The protein pellet was collected by centrifugation $\left(4^{\circ} \mathrm{C}, 10,000 \mathrm{rev} / \mathrm{min}, 30 \mathrm{~min}\right)$ and dissolved in $0.05 \mathrm{M}$ sodium citrate buffer, $\mathrm{pH}$ 5.0. Both extracts were dialyzed against the same buffer, centrifuged to separate the insoluble precipitate. $\alpha$-NaGalase activity was tested in both extracts and was found only in the protein fraction precipitated with $75 \%$ ammonium sulfate. This supernatant was used in further work as partly purified enzyme. The purification quality was controlled by $12 \%$ Laemmli-SDS-PAGE-electrophoresis [47].

\subsection{Production and Purification of Recombinant $\alpha$-D-galactosidase}

The recombinant wild-type $\alpha$-D-galactosidase ( $\alpha$-PsGal) was produced as described earlier [48]. The plasmid DNA pET-40b(+) containing insertion of the gene from the marine bacterium Pseudoalteromonas sp. KMM 701 encoding $\alpha$-PsGal was transformed in the Escherichia coli strain Rosetta (DE3). Heterological expression was carried out at optimal conditions as described earlier [49]. Purification of the recombinant $\alpha$-PaGal was performed, according to described procedures [48]. The purification quality was controlled by $12 \%$ Laemmli-SDS-PAGE-electrophoresis [47].

\subsection{Enzyme Assay}

The activity of $\alpha$-PsGal and $\alpha$-NaGalase were determined by increasing the amount of p-nithrophenol (pNP). To assay the $\alpha-\mathrm{NaGalase}$ activity $0.05 \mathrm{~mL}$ of cell extract and $0.1 \mathrm{~mL}$ of substrate pNPNA- $\alpha-\mathrm{Gal}(8.8 \mathrm{mM})$ in $0.05 \mathrm{M}$ sodium citrate buffer, $\mathrm{pH} 5.0$ were placed in cells of 96 -well plate and incubated at $37^{\circ} \mathrm{C}$ for $30 \mathrm{~min}$. The mixtures containing $0.05 \mathrm{~mL}$ of an enzyme solution and $0.1 \mathrm{~mL}$ of a substrate solution $(3.3 \mathrm{mM})$ in $0.05 \mathrm{M}$ sodium phosphate buffer ( $\mathrm{pH} 7.0$ ) were incubated at $20^{\circ} \mathrm{C}$ during 5 min for determination of $\alpha$-PsGal standard activity. The reactions were stopped by the addition of $0.15 \mathrm{~mL}$ of $1 \mathrm{M}$ $\mathrm{Na}_{2} \mathrm{CO}_{3}$ solution.

Absorbance was measured at $400 \mathrm{~nm}$. Results were read with a computer program Gen5 and treated with ExCel computer program. The unit of standard activity (U) was defined as the amount of the enzyme catalyzing the formation of $1 \mu \mathrm{mol}$ of p-nitrophenol $\left(\varepsilon_{400}=18,300 \mathrm{M}^{-1} \mathrm{~cm}^{-1}\right)$ per 1 min under the conditions indicated. Specific activity (A) was calculated as the enzyme activity $(\mathrm{U})$ per $1 \mathrm{mg}$ of protein. All calculations were based on reactions with consumption of $10 \%$ of the chromogenic substrate. The protein concentrations were estimated by the Bradford method with BSA as a standard [50]. Residual activity (\%) was calculated with formula: Residual activity $(\%)=v / v_{0} \times 100$, where $v$ is the initial reaction rate of enzymes under the action of an inhibitor or other factors, $v_{0}$ is the initial reaction rate of enzymes in the absence of the influence of any factors. Buffer solutions of $\alpha$-PsGal $(0.1 \mathrm{U} / \mathrm{mL})$ and $\alpha$-NaGalase $(0.01 \mathrm{U} / \mathrm{mL})$ were used in the further experiments.

\subsection{The Inhibitory Potency of the Compounds 1-9 for the $\alpha$-PsGal and $\alpha-N a G a l a s e$}

To preliminary test the inhibitory potency of the compounds $25 \mu \mathrm{L}$ the enzyme solutions of $\alpha$-PsGal in $0.05 \mathrm{M}$ sodium phosphate buffer ( $\mathrm{pH} 7.0$ ) or $\alpha$-NaGalase in $0.05 \mathrm{M}$ sodium citrate buffer ( $\mathrm{pH} 5.0$ ) were preincubated for $25 \mathrm{~min}$ at $20{ }^{\circ} \mathrm{C}$ with $5 \mu \mathrm{L}$ of water soluble or $2 \mu \mathrm{L}$ of ethanol soluble test compounds at various concentrations, respectively (from $10^{-3} \mathrm{M}$ to $10^{-7} \mathrm{M}$ in a probe), to allow enzyme and inhibitor interaction. In the control sample, $5 \mu \mathrm{L}$ of water or $2 \mu \mathrm{L}$ of $\mathrm{EtOH}$ were added to $25 \mu \mathrm{L}$ of enzyme solution. The enzyme reaction was initiated by adding $120 \mu \mathrm{L}$ of the substrate pNP- $\alpha$-Gal $(3.3 \mathrm{mM})$ for $\alpha$-PsGal or pNPNA- $\alpha$-Gal $(8.8 \mathrm{mM})$ for $\alpha$-NaGalase in the respective buffer solutions. After $10 \mathrm{~min}$ for $\alpha$-PsGal or $60 \mathrm{~min}$ for $\alpha$-NaGalase the reaction was stopped by adding $150 \mu \mathrm{L}$ 
of $1 \mathrm{M} \mathrm{Na}_{2} \mathrm{CO}_{3}$. The amount of pNP was quantified by spectrophotometric detection at $400 \mathrm{~nm}$. Results were evaluated as the percent of residual activity as described above.

\subsection{The Irreversibility of $\alpha$-PsGal Inhibition by Alkaloids}

To determine the reversibility of the $\alpha$-PsGal activity inhibition by alkaloids $2,3,8$, and $915 \mu \mathrm{L}$ of $0.625 \mathrm{mM}$ aqueous solution of the compounds 2 and 3 or $6 \mu \mathrm{L}$ of $2.5 \mathrm{mM}$ ethanol solution of the compound 8 and 9 were added to $75 \mu \mathrm{L}$ of the enzyme solution in $0.05 \mathrm{M}$ sodium phosphate buffer ( $\mathrm{pH} 7.0$ ). After $30 \mathrm{~min}$ of the mixture incubation the aliquot of $30 \mu \mathrm{L}$ was taken and $120 \mu \mathrm{L}$ of $3.3 \mathrm{mM}$ pNPG solution were added to initiate the reaction; the reaction was stopped by addition of $150 \mu \mathrm{L}$ of $1 \mathrm{M} \mathrm{Na}_{2} \mathrm{CO}_{3}$. The $\alpha$-D-galactosidase activity was determined, as described above. The remaining reaction mixture was dialyzed against $1 \mathrm{~L}$ of $0.02 \mathrm{M}$ sodium phosphate buffer $(\mathrm{pH} 7.0)$ for $60 \mathrm{~h}$ at $4{ }^{\circ} \mathrm{C}$. The buffer was changed 3 times during the dialysis. The enzyme activity was determined, as described above. A sample of $\alpha$-PsGal treated with $\mathrm{H}_{2} \mathrm{O}$ or EtOH in the absence of the inhibitor (75 $\mu \mathrm{L}$ of the enzyme solution and $15 \mu \mathrm{L}$ of $\mathrm{H}_{2} \mathrm{O}$ or $6 \mu \mathrm{L}$ of EtOH, respectively) was dialyzed and used as a control for determination of the initial activity. The experiment was carried out in two replicates. The residual activity was calculated as described above.

\subsection{Kinetic Studies on 2, 3, 8 and 9 against the $\alpha$-PsGal}

The kinetic parameters $K_{i}$ and $k_{\text {inact }}$ were determined by classic methods [51]. The inactivation of $\alpha$-PsGal was monitored by incubation of the enzyme with different concentrations of alkaloids in $0.02 \mathrm{mM}$ sodium phosphate buffer, $\mathrm{pH} 7.0$, at $20^{\circ} \mathrm{C}$ in total volume of $30 \mu \mathrm{L}(25 \mu \mathrm{L}$ and $5 \mu \mathrm{L}$ of $\alpha$-PsGal and alkaloids, respectively), which were placed in cells of 96 cells plate. After preincubation of enzyme-inhibitor mixture for 0.5, 5, 10, 15, 20,25 , or $30 \mathrm{~min} 120 \mu \mathrm{L}$ the fraction of remaining enzyme activity was measured as a function of time by addition to the inactivation mixture $120 \mu \mathrm{L}$ of a solution of pNP- $\alpha$-Gal $(3.3 \mathrm{mM})$. The pseudo-first-order rate constant of inactivation $\left(k_{\mathrm{obs}}\right)$ was determined for each inactivator concentration as the slope of the $\mathrm{v} / \mathrm{v}_{0}$ dependence on the incubation time in semilogarithmic coordinates. The Excel software was used for these calculations. The second order rate constants for the inactivation process were determined by fitting the dependences of the $k_{\mathrm{obs}}$ values on the concentration of the inactivators to the Hill or Michaelis-Menten equations. An analysis of the graphs and the choice of models for calculation of inhibition constants $\left(K_{i}, \mathrm{mM}\right)$ and inactivation rate constants $\left(k_{\text {inact }}, \mathrm{min}^{-1}\right)$ were performed with the Origin computer software.

\subsection{Theoretical Models of $\alpha$-D-Galactosidase Complexes with Aaptamine and Makaluvamine Alkaloids}

The 3D model of $\alpha$-D-galactosidase (GenBank: ABF72189.2) was built using the Molecular Operating Environment version 2020.09 package (MOE, 2020.09; Chemical Computing Group ULC, 1010 Sherbrooke St. West, Suite \#910, Montreal, QC, Canada, H3A 2R7, 2020), as described earlier [39,40]. Structures of alkaloids were obtained from the PubChem database and optimized using the MOE program. The evaluation of structural parameters, contact structure analysis, molecular docking, and visualization of the results were carried out with the Dock and Ligand interaction modules in the MOE 2020.09 program. The results were obtained using the equipment of Shared Resource Center Far Eastern Computing Resource of Institute of Automation and Control Processes Far Eastern Branch of the Russian Academy of Sciences (IACP FEB RAS, available online: https: / / cc.dvo.ru (accessed on 30 November 2020).

\section{Results and Discussion}

\subsection{Identification of the Compounds}

For the present study, alkaloids were reisolated from repository samples of marine sponges Aaptos aaptos and Zyzzya fuliginosa. Aaptamine (1) [12], isoaaptamine (2) [14], 9-demethylaaptamine (3) [41], and aaptanone (4) [41] were reisolated from a sample of the marine sponge A. aaptos. Damirones A (5) and B (6) [43], makaluvamines H (7) [44] 
and G (8) [45], and zyzzyanone A (9) [46] were reisolated from a sample of the marine sponge Z. fuliginosa. Compounds 1-9 were identified by comparison of their spectroscopic data $\left({ }^{1} \mathrm{H}-,{ }^{13} \mathrm{C}-\mathrm{NMR}, \mathrm{HREI}\right.$ MS, HRFAB MS) with published values [12,14,41-46], respectively. Structures of these alkaloids are shown in Table 2. These compounds present two classes of alkaloids. Aaptamine class includes aaptamine (1), isoaaptamine (2), and 9-demethylaaptamine (3), having 1,6-naphthyridine core fused with a functionalized benzenoid unit, and aaptanone (4), a zwitterionic metabolite bearing two adjacent carbonyl groups in the 1,6-naphthyridine core. Makaluvamine class includes damirones A (5) and $\mathrm{B}(6)$, makaluvamines $\mathrm{H}(7)$ and $\mathrm{G}(8)$ with a pyrrolo[4,3,2-de]quinoline core, and related zyzzyanone A (9) bearing dipyrroloquinone core.

\subsection{Cytotoxic Effect of Alkaloids on Human Colorectal Adenocarcinoma Cell Line DLD-1}

We have previously shown that the DLD-1 adenocarcinoma cell line expresses $\alpha$ $\mathrm{NaGalase}$ better than other cell lines, and this enzyme was well characterized [37]. Therefore, for research the effect of alkaloids on the enzyme expression, we used the cell line DLD-1. We investigated the effect of sponge-derived alkaloids on $\alpha$-NaGalase activity in human cancer cells using two assays: one was a treatment of DLD cells with alkaloids (in vitro); the other was a direct treatment with alkaloids of isolated and purified $\alpha-\mathrm{NaGalase}$ from lysates of various cancer cell lines.

As a first step, the effect of compounds 1-9 on the viability of human colorectal carcinoma DLD-1 cells was tested by MTS assay to determine their non-toxic concentration. It was shown that compounds 1, 4-9 are non-cytotoxic against DLD-1 cells at the dose up to $20 \mu \mathrm{M}$. Compound 2 was weakly cytotoxic: the decrease in cell viability was $20 \%$ at $20 \mu \mathrm{M}$. The concentration of compound 3 that caused a $50 \%$ reduction in cell viability $\left(\mathrm{IC}_{50}\right)$ of DLD- 1 cells was $17 \pm 0.2 \mu \mathrm{M}$. DLD- 1 cells possessed $100 \%$ viability after treatment with $5 \mu \mathrm{M}$ concentration of compounds.

\subsection{Inhibitory Potency of Aaptamine and Makaluvamine Classes of Alkaloids on the $\alpha$-NaGalase of Cancer Cells}

All alkaloids 1-9 were tested on their influence on the hydrolyzing activity of the $\alpha-\mathrm{NaGalase}$ isolated from cells of human carcinoma DLD-1, HT-29 and HCT-116, breast cancer MDA-MB-231, melanoma SK-MEL-5 and RPMI-7951, and mouse healthy epidermal cells JB6 Cl41. Our experiments showed that none of the tested compounds 1-9 had any direct inhibitory effects on the activity not only against human cancer cell $\alpha-\mathrm{NaGalase}$ as well against $\alpha$-NaGalase from mouse healthy epidermal cells. However, isoaaptamine (2), 9-demethylaaptamine (3), damirone B (6) and makaluvamine $\mathrm{H}$ (7) reduced the expression of the enzyme in the human colorectal adenocarcinoma cell line DLD-1 from 100\% to 64, 57,52 , and $50 \%$, respectively, at concentration $5 \mu \mathrm{M}$ (Figure 1).

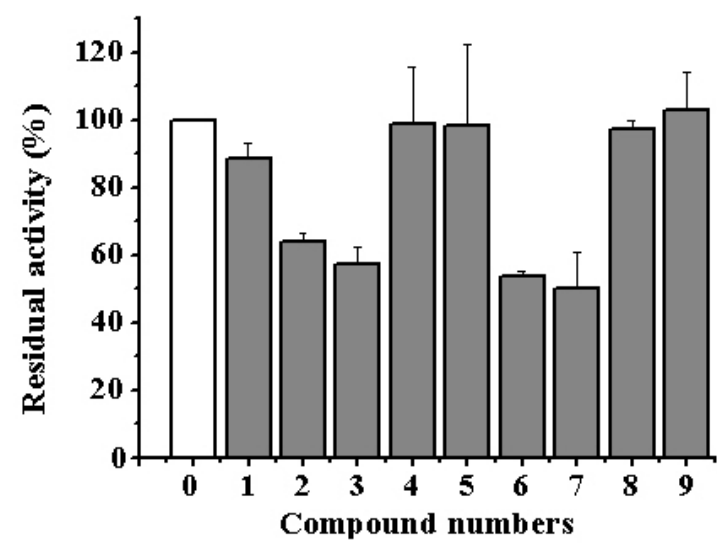

Figure 1. Residual activity of lysate cell $\alpha$-NaGalase after treatment of colon cancer cells DLD-1 with $5 \mu \mathrm{M}$ of aaptamine (1), isoaaptamine (2), 9-demethylaaptamine (3), aaptanone (4), damirone A (5), 
damirone B (6), makaluvamine $H$ (7), makaluvamine $G(8)$, zyzzyanone A (9) relative to the enzyme of untreated cells as positive control (0). Residual activity of $\alpha$-NaGalase was defined as $\mathrm{A} / \mathrm{A}_{0} \times 100(\%)$, where $\mathrm{A}$ and $\mathrm{A}_{0}$ are the specific activities of $\alpha-\mathrm{NaGalase}$ of the samples (1-9) and the control experiment (0), respectively. Data are shown as means \pm standard deviation (SD) of values from three independent experiments $(p<0.05)$ evaluated by methods of descriptive statistics in software "Origin 8.1".

We observed a similar effect after treatmant with DLD-1 cells with sulfated polysaccharide fucoidan from brown alga Fucus evanescens [37]. Fucoidan significantly reduced the expression of the enzyme, but did not directly inhibit it. Currently, the information about correlation of activity or expression of $\alpha$-NaGalase with activation of receptors or proteins of signaling pathways, responsible for carcinogenesis, is absent in the literature.

3.4. Inhibitory Potency of Aaptamine and Makaluvamine Classes of Alkaloids on the $\alpha$-PsGal of the Marine Bacterium

According to the modern classification of carbohydrate active enzymes (CAZy), the $\alpha$-PsGal belongs to the GH36 family and $\alpha$-NaGalase from human cancer cells belongs to the GH27 family. These enzymes of the GH27 and GH36 families are related, they share a common gene and form clan D, the structure of their active center is very homologous [28]. Accordingly, we decided to test whether alkaloids will inhibit an marine bacterial enzyme closely related. We hoped that effective $\alpha$-PsGal inhibitors would inhibit the highly malignant $\alpha$-NaGalase enzyme in cells. All alkaloids 1-9 were tested on the hydrolyzing activity of the $\alpha$-PsGal isolated from a marine bacterium Pseudoalteromonas sp. KMM 701. There was no notable activity against $\alpha$-PsGal for aaptamine (1), aaptanone (4), damirones A (5) and $B(6)$, and makaluvamine $H(7)$ even at a high concentration of inhibitors (Table 1).

Table 1. Residual activity $v / v_{0}(\%)$ of the $\alpha$-PsGal after incubation with alkaloids 1-9.

\begin{tabular}{cccc}
\hline Compound & $v / v_{0}(\%)$ & Compound & $v / v_{0}(\%)$ \\
\hline $\mathbf{1}$ & $79^{1}$ & 6 & $87^{2}$ \\
$\mathbf{2}$ & $0^{1}$ & 7 & $67^{2}$ \\
$\mathbf{3}$ & $0^{1}$ & $\mathbf{8}$ & $28^{2}$ \\
$\mathbf{4}$ & $100^{1}$ & 9 & $0^{2}$ \\
$\mathbf{5}$ & $87^{2}$ & $6.4 \% \mathrm{EtOH}$ & 100 \\
\hline
\end{tabular}

${ }^{1}$ Compound concentrations $1.67 \mathrm{mM} ;{ }^{2}$ compound concentrations $1.48 \mathrm{mM}$; the enzyme was preincubated with an inhibitor for $30 \mathrm{~min}, 20^{\circ} \mathrm{C}$, $\mathrm{pH} 7.0$.

The tested alkaloids to varying degrees inhibited the GH36 $\alpha$-PsGal. It is interesting to note that pentacyclic guanidine alkaloids from the sponge Monanchora pulchra inhibited only marine microbial enzymes (the $\alpha$-PsGal and 1,3-exo- $\beta$-D-glucanase from marine fungus Chaetomium indicum), but did not act on eukaryotic 1,3-endo- $\beta$-D-glucanase from marine mollusk Spisula sacchalinensis and the GH109 family $\alpha$-NaGalase from marine bacteria Arenibacter latericius KMM 426 ${ }^{\mathrm{T}}$ [40,52].

Of all tested alkaloids, only four compounds showed any inhibitory effects on the activity of the bacterial $\alpha$-PsGal. They are isoaaptamine (2), 9-demethylaaptamine (3), makaluvamine G (8), and zyzzyanone A (9) (Table 1). It was shown that inhibitors 2, 3, 8, and 9 irreversibly inactivate the $\alpha$-PsGal. The irreversible inhibition was confirmed by the dialysis experiment. The activity of the enzyme did not recover after dialysis against the buffer solution for $60 \mathrm{~h}$, but the enzyme in the absence of the inhibitor keeps 100\% activity during this dialysis process.

\subsection{Kinetic Studies on 2, 3, 8, and 9 against the $\alpha-P s G a l$}

To investigate a possible mode of interaction of these alkaloids with the $\alpha$-PsGal, kinetic studies were done. The results of kinetic studies of the $\alpha$-PsGal inactivation by the action of the spongean alkaloids 2, 3, 8, and 9 are shown in Figure 2. Because of the 
$\alpha$-PsGal inactivation developed relatively slowly, within a few minutes under experimental conditions, the inhibitory activity of the compounds can be described by the inactivation rate constant $\left(k_{\text {inact }}, \min ^{-1}\right)$ and equilibrium inhibition constant $K_{i}$ [53]. The kinetic Equation (1) describes the irreversible slow inhibition of the $\alpha$-PsGal under the action of alkaloids 2 , 3,8 , and 9 :

$$
\begin{aligned}
& K_{i} \quad k_{\text {inact }} \\
& \mathrm{E}+\mathrm{In} \rightleftharpoons\left[\mathrm{E} \cdot \mathrm{I}^{\mathrm{n}}\right] \rightarrow \mathrm{E}-\mathrm{I}^{\mathrm{n}}
\end{aligned}
$$

where $\mathrm{E}$ is enzyme; $\mathrm{I}$ is inhibitor; $\mathrm{n}$ is Hill's coefficient of cooperativity.

(a) (i)

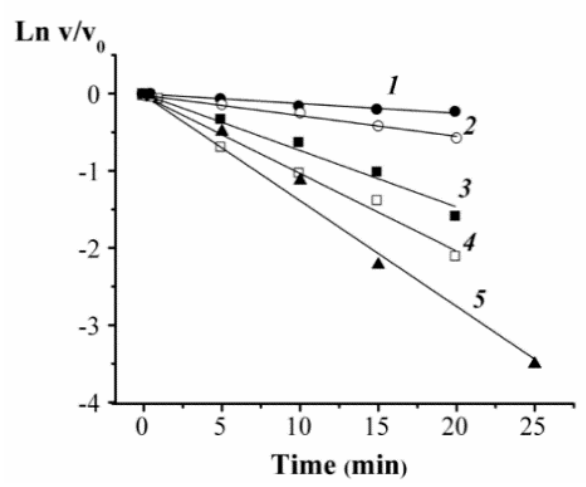

(b) (i)

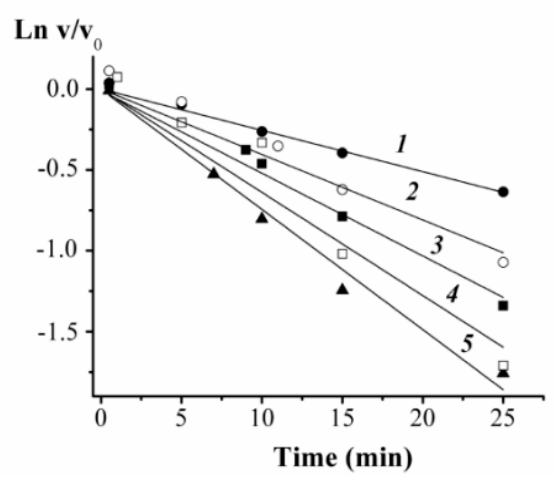

(c) (i)

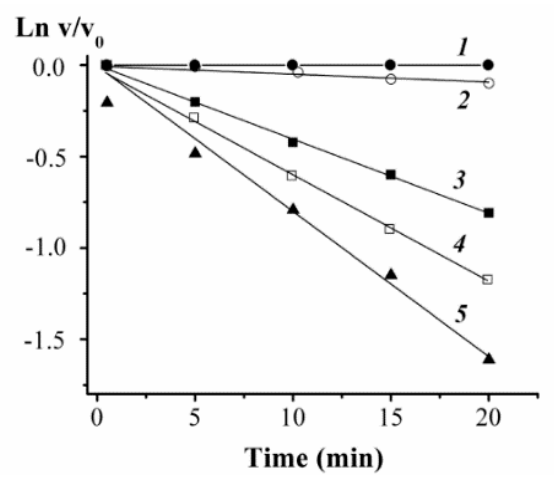

(a) (ii)



(b) (ii)

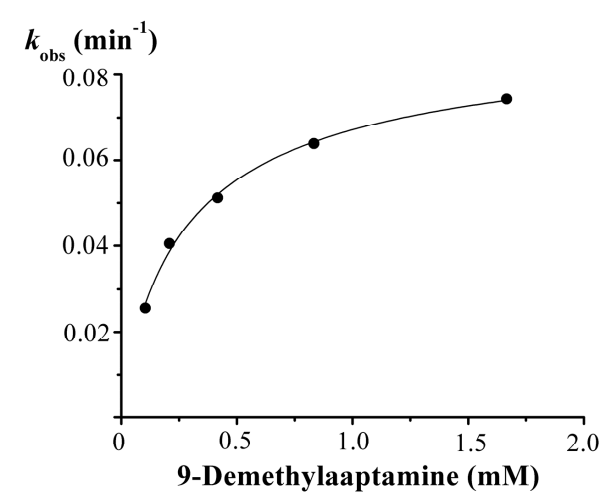

(c) (ii)

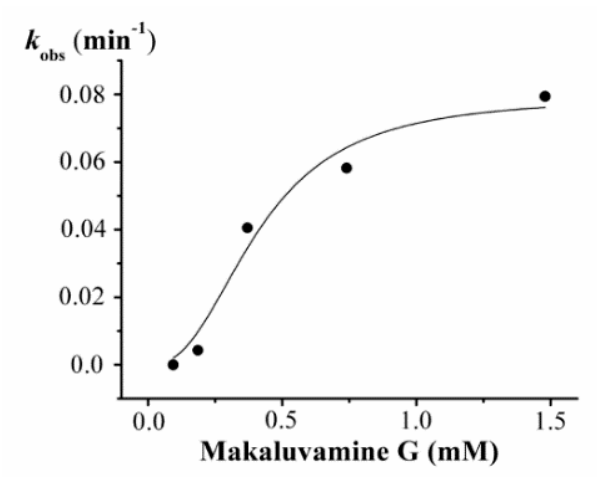

Figure 2. Cont. 
(d) (i)



(d) (ii)



Figure 2. The results of kinetic studies of the $\alpha$-PsGal inactivation by tested alkaloids: (i) the kinetic change of the residual activity of the enzyme $\left(v / v_{0}\right)$ in semilogarithmic coordinates at the presence of different concentrations of alkaloids; (ii) the inactivation rate $\left(k_{\mathrm{obs}}\right)$ dependence on the concentration of alkaloids; (a) isoaaptamine: $814 \mu \mathrm{M}(1), 1.63 \mu \mathrm{M}(2), 3.255 \mu \mathrm{M}(3)$, $6.51 \mu \mathrm{M}$ (4), $10.417 \mu \mathrm{M}$ (5); (b) 9-demethylaptamine: $0.104 \mathrm{mM}$ (1), $0.208 \mathrm{mM}$ (2), $0.417 \mathrm{mM}$ (3), $0.833 \mathrm{mM}$ (4), $1.67 \mathrm{mM}$ (5); (c) makaluvamin G: $0.093 \mathrm{mM}$ (1), $0.185 \mathrm{mM}$ (2), $0.37 \mathrm{mM}$ (3), $0.74 \mathrm{mM}$ (4), $1.48 \mathrm{mM}$ (5); (d) zyzzyanone A: $0.0116 \mathrm{mM}$ (1), $0.023 \mathrm{mM}(2), 0.046 \mathrm{mM}(3), 0.093 \mathrm{mM}$ (4), $0.185 \mathrm{mM}$ (5), $0.37 \mathrm{mM}$ (6). All of the experiments were performed in duplicates.

Alkaloids 2, 3, 8, and 9 exhibited a time- and concentration-dependent inhibitory manner suggesting that the inhibition was irreversible. The curves of the dependences of the residual activity $v / v_{0}$ on the time in semilogarithmic coordinates are shown in Figure 2(i) (a, b, c, d). The inactivation rate constant $\left(k_{\text {obs }}\right)$, as can be seen in Figure 2(ii) (a, b, $c, d)$ is inhibitor concentration dependent and a gradual increase in inhibitor concentration increases the inactivation rate constant. The nonlinear S-shaped curves of $k_{\mathrm{obs}}$ dependence on a concentration of compounds 2, 3, 8, and 9 (Figure 2(ii)) mean that inhibition of the $\alpha$-PsGal by these slowly binding irreversible inhibitors is cooperative and occurs in two stages: (1) the formation reversible enzyme-inhibitor complex (E.I) and (2) irreversible inhibition of the enzyme in this complex (E-I). The experimental dependences of $k_{\mathrm{obs}}$ on the concentration of the compounds 2, 3, 8, and 9 (Figure 2(ii)) more exactly are approximated by the Hill's Equation (2). Values of true $K_{i}$ and $k_{\text {inact }}$, as well as Hill's cooperativity coefficients are given in Table 2.

$$
k_{\mathrm{obs}}=\frac{k_{\text {inact }} \mathrm{I}^{\mathrm{n}}}{\left(K_{i}^{\mathrm{n}}+\mathrm{I}^{\mathrm{n}}\right)}
$$

Of the group aaptamine alkaloids, only isoaaptamine (2) and 9-demethylaaptamine (3) showed inhibitory activity against the $\alpha$-PsGal. As can be seen in Table 2 isoaaptamine (2) $\left(K_{i}=2.7 \mu \mathrm{M}\right)$ is significantly more active if compared with 9-demethylaaptamine (3) $\left(K_{i}=300 \mu \mathrm{M}\right)$, although their inactivation rate constants are almost equal $\left(k_{\text {inact }} 0.12\right.$ and $0.092 \mathrm{~min}^{-1}$, respectively). More active inhibitor 2 shows positive cooperative binding with $\alpha$-PsGal with $n>1(n=2.17)$, i.e., binding of one molecule of 2 with the enzyme increases enzyme affinity for other molecules of this inhibitor. In contrast, less active 3 displays negative cooperative binding with $\mathrm{n}<1 \quad(n=0.84)$; binding of one molecule of 3 decreases enzyme affinity for other molecules of 3 . Structurally, these inhibitors differ only slightly, compound 3 is the non-N1-methylated analogue of compound 2. A substitution pattern in a benzenoid part of compounds $\mathbf{2}$ and $\mathbf{3}$ is the same; both inhibitors have a hydroxyl group at C-9 position in contrast to compounds $\mathbf{1}$ and 4 . The increased activity of $\mathbf{2}$ in comparison with 3 is presumably the consequence of the presence of the methyl group at N1 of a 1,6-naphthiridine core. Thus, the presence of the hydroxyl group at C-9 and the methyl group at the $\mathrm{N}-1$ in a benzo-1,6-naphthiridine core are important factors for $\alpha$-PsGal inhibition. Such observation was reported earlier for 2, which showed higher activity in inhibition of sortase A, compared with $\mathbf{1}$ and $\mathbf{3}$ [18]. Isoaaptamine (2) also was 
more active than aaptamine (1) in inhibiting $\beta$-1,3-glucanase of marine mollusks [20]. Small structural differences in aaptamine (1) and aaptanone (4) (Table 2) in comparison with 2 and 3 resulted in loss of their inhibitory potency on the $\alpha$-PsGal.

Table 2. Structures of tested spongean alkaloids and $\alpha$-PsGal inhibition constants for 2, 3, 8, and 9.

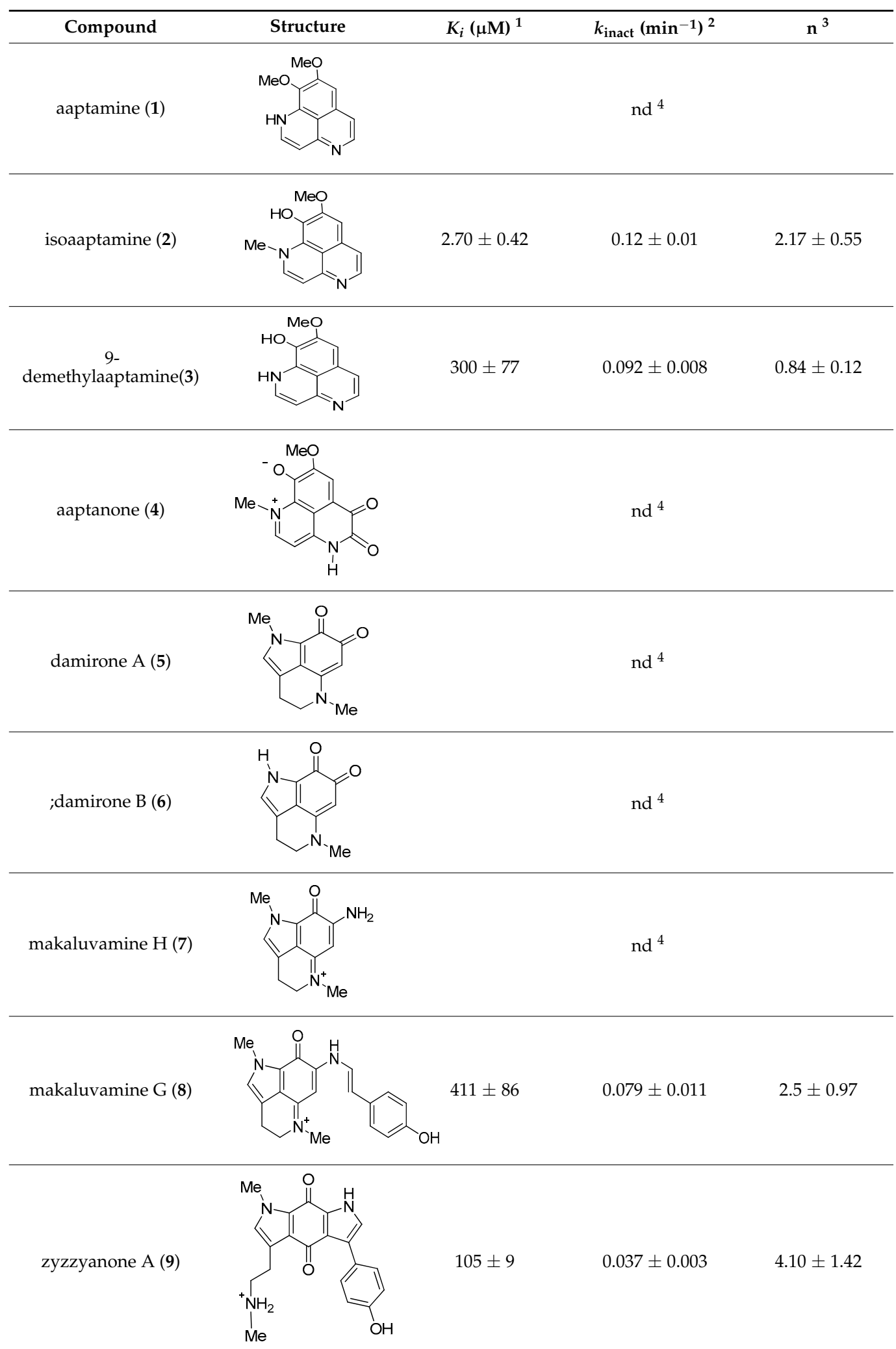

${ }^{1} K_{i}$-equilibrium inhibition constant; ${ }^{2} k_{\text {inact }}$-inactivation rate constant; ${ }^{3} \mathrm{n}$-Hill's coefficient of cooperativity; ${ }^{4}$ not determined. 
Among the test alkaloids of the makaluvamine group, makaluvamine G (8) and zyzzyanone A (9) showed low inhibitory activity against the $\alpha$-PsGal. Nonetheless, zyzzyanone A (9) $\left(K_{i}=105 \mu \mathrm{M}\right)$ is more active than makaluvamine $\mathrm{G}(8)\left(K_{i}=411 \mu \mathrm{M}\right)$, but inactivation rate of $9\left(0.037 \mathrm{~min}^{-1}\right)$ is almost twice lower that of $8\left(0.079 \mathrm{~min}^{-1}\right)$ (Table 2). The methylaminoethyl side chain and/or rigid planar dipyrroloquinone core of $\mathbf{9}$, apparently, slowly penetrate into the active site of $\alpha$-PsGal reducing the rate of enzyme inactivation. More active inhibitor 9 shows higher coefficient of cooperativity $(n=4.1)$ than less active inhibitor $8(n=2.5)$. Comparing structures of alkaloids from the makaluvamine group it can be seen that both metabolites $\mathbf{8}$ and $\mathbf{9}$ have a hydroxyphenyl ring in their structure. Probably, the increased electron density of the hydroxyphenyl ring would facilitate non-covalent $\pi-\pi$ interactions of these compounds with protein residues in the catalytic or allosteric sites of the enzyme. Earlier it has been shown that pentacyclic guanidine alkaloids from the sponge Monanchora pulchra also are slow-binding irreversible inhibitors of the $\alpha$-PsGal without the formation of covalent bonds with amino acids of the enzyme active center [40].

\subsection{Theoretical Models of $\alpha$-D-Galactosidase Complexes with Aaptamine and Makaluvamine Alkaloids}

To support the active-site-directed nature of the $\alpha$-D-galactosidase inactivation and assess possible binding sites for inhibitors a molecular docking of the active alkaloids 2, 3,8 , and 9 was performed on the predicted 3D structure of the $\alpha$-D-galactosidase active center [54]. Homology model of the $\alpha$-PsGal 3D-structure was constructed earlier by molecular docking in the MOE program [54] using the crystal structure of the $\alpha$-galactosidase from Lactobacillus acidophilus of GH36 family as template [55]. The active center of the $\alpha$-Dgalactosidase is located in the central $(\beta / \alpha)_{8}$ domain, Asp451 and Asp516 are the catalytic nucleophile and acid/base residues, respectively. Another highly conserved residue in the active center is Trp308. The enzyme $\alpha$-PsGal is a typical O-glycoside hydrolase of the GH36 family. It was previously shown that its molecule consists of two identical subunits $[29,30]$. The computer model of the enzyme has previously been successfully used for the analysis of $\alpha$-PsGal complexes with low molecular weight inhibitors [39,40,54].

Molecular docking of the alkaloids isoaaptamine (2), 9-demethylaaptamine (3), makaluvamine G (8), and zyzzyanone A (9) with $\alpha$-PsGal showed that all studied compounds form complexes with the active site of the enzyme. The key interactions of these inhibitors with the active site of the $\alpha$-D-galactosidase are shown in Figure 3. The complexes of the alkaloids with the $\alpha$-PsGal active center are stabilized by $\pi-\pi$ interactions with functionally important residue Trp308. Moreover, all alkaloids form H-bonds with residue Lys449. As can be seen from superposition of complexes of compound 2, 3, 8, 9, and D-Gal with the active center of the enzyme (Figure 4), the alkaloids shared space in the active center with $\mathrm{D}$-Gal. This indicates the active-site-directed nature of the $\alpha$-D-galactosidase inactivation by the tested compounds. Although the alkaloids 2, 3, 8, and 9 did not directly interact with catalytic residues Asp451 and Asp516, tricyclic parts of alkaloids located deeply in the active center block the access of the substrate into the pocket of the active center to the catalytic residues Asp451 and Asp516.

None of the studied alkaloids formed complexes with the active site of human $\alpha$ $\mathrm{NaGalase}$. If, in the case of $\alpha$-PsGal, isoaaptamine binds to the active site of the enzyme, then, in the case of $\alpha-\mathrm{NaGalase}$, binding sites of the alkaloid are located outside the active site of the enzyme (Figure 5). Therefore, bound isoaaptamine has not decreased the activity of cancer $\alpha-\mathrm{NaGalase}$. 
Isoaaptamine

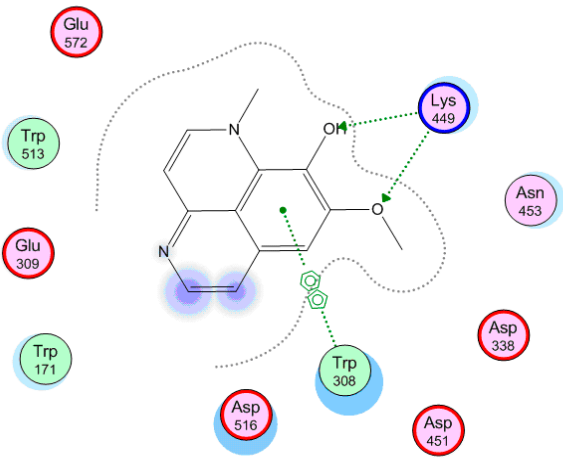

Makaluvamine G

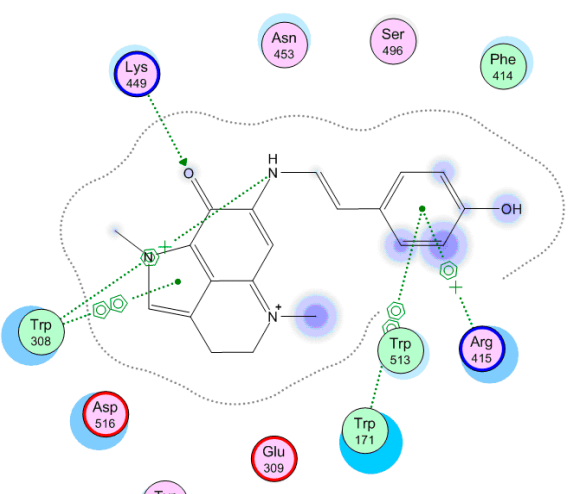

$\left(\begin{array}{c}\text { Asn } \\ 518\end{array}\right.$

Tyr
312

110
550
5
9-Demethylaaptamine

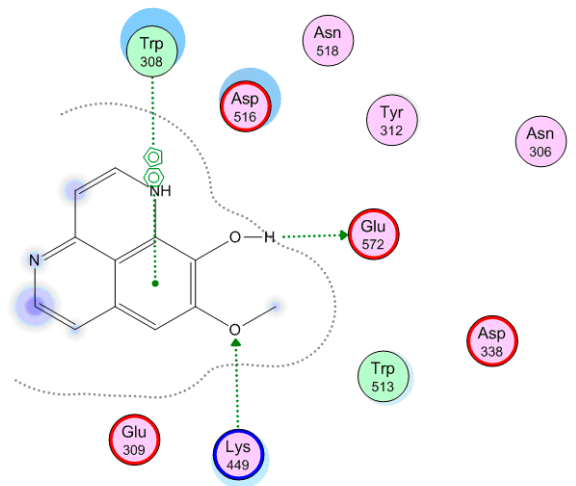

Zyzzyanone A

110
550

(Ser

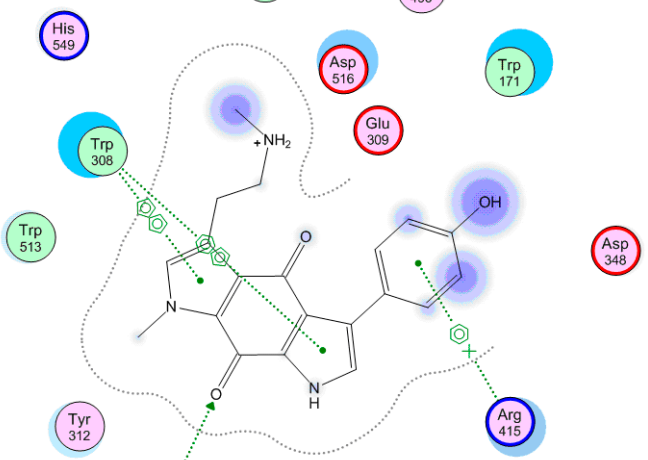

(L45)

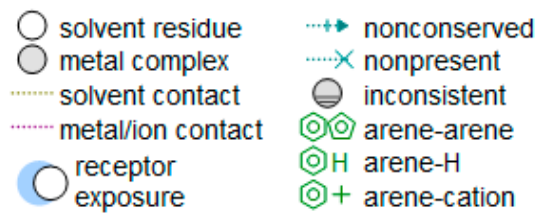

$\bigcirc$ solvent residue $\quad \cdots \rightarrow$ nonconserved

polar $\quad \cdots . \rightarrow$ sidechain acceptor

acidic $\quad$ *.... sidechain donor

$\bigcirc$ basic $\quad \rightarrow \rightarrow$ backbone acceptor

greasy $\$$ backbone donor

proximity ligand

exposure

Oeceptor

(2) $\mathrm{H}$ arene-H

(b) arene-cation

Figure 3. 2D-diagrams of the $\alpha$-PsGal complexes with alkaloids of aaptamine and makaluvamine classes.

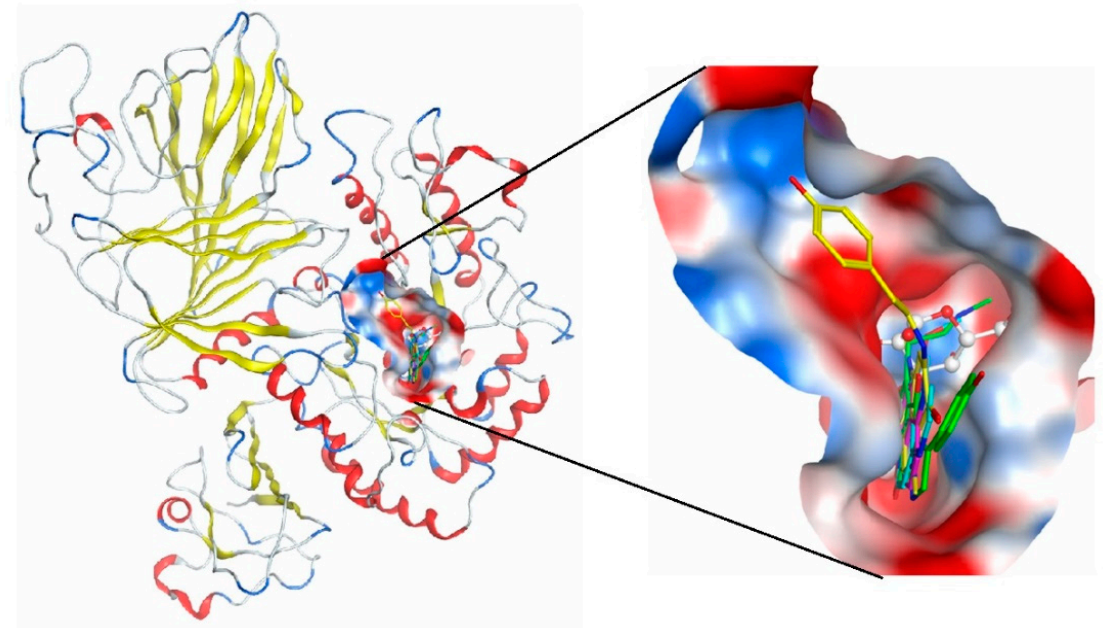

Figure 4. Superpositions of alkaloids 2, 3, 8, 9, and D-galactose in the active site of $\alpha$-D-galactosidase. Ligands are shown as sticks. Isoaaptamine (2) is shown in pink; 9-demethylaaptamine (3) is shown 
in cyan; makaluvamine G (8) is shown in yellow; zyzzyanone A (9) is shown in green; D-galactose is shown in white. The molecular surface of the catalytic domain binding site is shown in red (negative), blue (positive), and gray (neutral) classes.
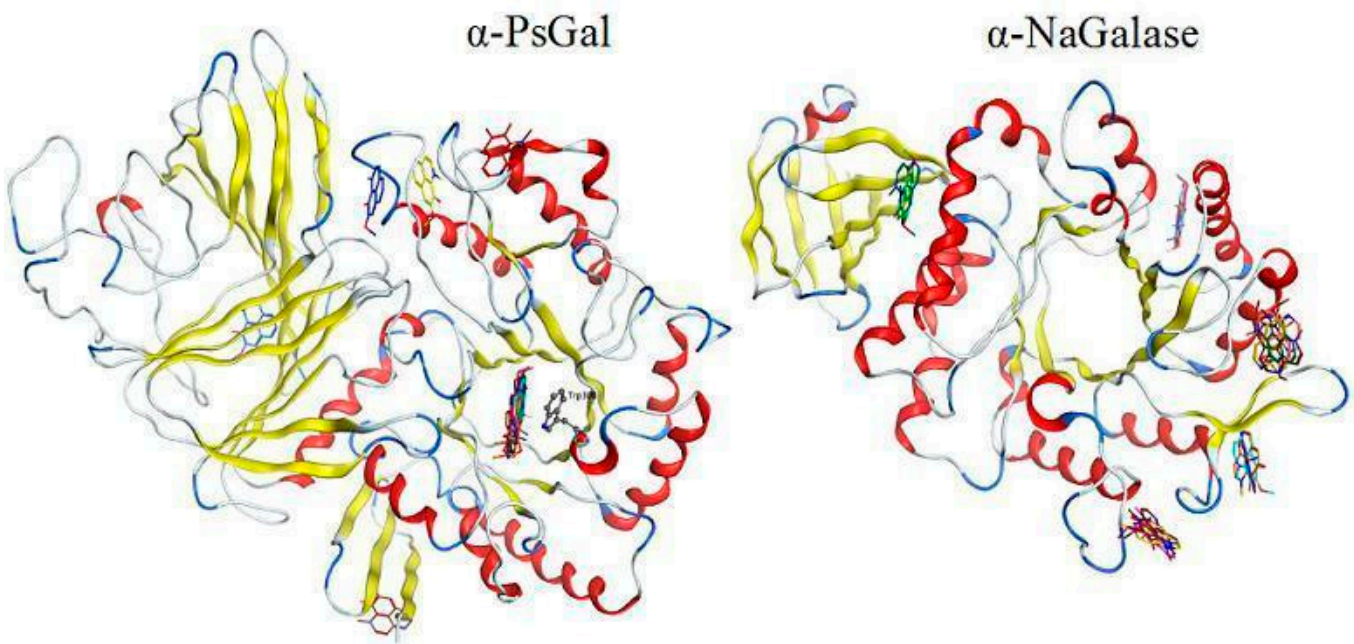

Figure 5. Superposition of the 20 most beneficial complexes of isoaaptamine with one subunit of bacterial $\alpha$-D-galactosidase of GH36 family and human lysosomal $\alpha$-NaGalase (Protein Data Bank: 3H54) of GH27 family. Protein structures are shown in ribbon diagrams, the isoaaptamine molecule is shown as sticks. The structures of the complexes were calculated using the GRAMM program.

\section{Conclusions}

We used two related $\alpha$-glycosidases of Clan D: $\alpha$-N-acetylgalactosaminidase ( $\alpha$ NaGalase) of the GH27 family from different human cancer cells and $\alpha$-galactosidase ( $\alpha$-PsGal) of the GH36 family from the marine bacterium Pseudoalteromonas sp. KMM 701 to study the effect of the well-known marine sponge metabolites with a therapeutic potential and clarify the possible mechanism of their inhibitory action. The well-characterized $\alpha$-PsGal has been proved to be a suitable model for characterizing the novel properties of the alkaloids. Isoaaptamine (2), 9-demethylaaptamine (3), makaluvamine G (8), and zyzzyanone A (9) have been shown to be irreversible slow-binding inhibitors of the $\alpha$ PsGal of the GH36 family. The inhibitory ability of these alkaloids depends on the chemical structure of their molecules. The presence of the hydroxyl group at C-9 position and the N1-methyl group on a benzo-1,6-naphthyridine skeleton are important factors for $\alpha$-PsGal inhibition by aaptamine alkaloids. A hydroxyphenyl ring in makaluvamine $\mathrm{G}$ and zyzzyanone $\mathrm{A}$ is important structural feature for their activity against the $\alpha$-PsGal. Our findings have demonstrated the potential of marine natural products to be a prototype of the $\alpha$-galactosidase inhibitors. However, these highly active marine compounds act selectively on carbohydrases; they have no direct inhibitory effect on the activity of the cancer $\alpha$-NaGalase of the GH27 family. Therefore, the expected properties, similar to those of $\alpha$-PsGal, in the related eukaryotic enzyme ( $\alpha$-NaGalase) were not confirmed. It is interesting to note that the same compounds isoaaptamine (2), 9-demethylaaptamine (3), and two other compounds damirone B (6) and makaluvamine $\mathrm{H}$ (7) reduced the expression of the enzyme in the cell line DLD-1 at non cytotoxic concentration $5 \mu \mathrm{M}$. However, further in vitro and in vivo studies are needed to study the mechanism of molecular suppression of $\alpha-\mathrm{NaGalase}$ in cancer cells.

Author Contributions: Design of the study: I.B. and N.U.; isolation and purification of human cancer cell enzyme, enzyme investigation: I.B.; bioinformatics analysis and computer modeling of protein-inhibitor complex structures: G.L.; construction, expression, and purification of recombinant enzyme: L.B. and L.S.; cell culturing: O.M. and S.E.; purification and identification of compounds: 
N.U.; writing of the manuscript: N.U. and I.B. All authors have read and agreed to the published version of the manuscript.

Funding: This research was funded by RFBR (Russian Foundation for Basic Research), grant number 20-04-00591.

Institutional Review Board Statement: Not applicable.

Informed Consent Statement: Not applicable.

Data Availability Statement: Not applicable.

Acknowledgments: Authors acknowledge Anastasia Zueva for technical support.

Conflicts of Interest: The authors declare no conflict of interest. The funders had no role in the design of the study; in the collection, analyses, or interpretation of data; in the writing of the manuscript, or in the decision to publish the results.

\section{References}

1. Carroll, A.R.; Copp, B.R.; Davis, R.A.; Keyzers, R.A.; Prinsep, M.R. Marine natural products. Nat. Prod. Rep. 2020, 37, 175-223. [CrossRef]

2. Antunes, E.M.; Copp, B.R.; Davies-Coleman, M.T.; Samaai, T. Pyrroloiminoquinone and related metabolites from marine sponges Nat. Prod. Rep. 2005, 22, 62-72. [CrossRef] [PubMed]

3. Nijampatnam, B.; Nadkarni, D.H.; Wu, H.; Velu, S.E. Antibacterial and antibiofilm activities of makaluvamine analogs. Microorganisms 2014, 2, 128-139. [CrossRef] [PubMed]

4. Alonso, E.; Alvariño, R.; Leirós, M.; Tabudravu, J.N.; Feussner, K.; Dam, M.A.; Rateb, M.E.; Jaspars, M.; Botana, L.M. Evaluation of the Antioxidant activity of the marine pyrroloiminoquinone makaluvamines. Mar. Drugs 2016, 14, 197. [CrossRef]

5. Davis, R.A.; Buchanan, M.S.; Duffy, S.; Avery, V.M.; Charman, S.A.; Charman, W.N.; White, K.L.; Shackleford, D.M.; Edstein, M.D.; Andrews, K.T.; et al. Antimalarial activity of pyrroloiminoquinones from the Australian marine sponge Zyzzya sp. J. Med. Chem. 2012, 55, 5851-5858. [CrossRef] [PubMed]

6. Goey, A.K.; Chau, C.H.; Sissung, T.M.; Cook, K.M.; Venzon, D.J.; Castro, A.; Ransom, T.R.; Henrich, C.J.; McKee, T.C.; McMahon, J.B.; et al. Screening and biological effects of marine pyrroloiminoquinone alkaloids: Potential inhibitors of the HIF-1 $\alpha /$ p300 interaction. J. Nat. Prod. 2016, 79, 1267-1275. [CrossRef]

7. Chen, T.; Xu, Y.; Guo, H.; Liu, Y.; Hu, P.; Yang, X.; Li, X.; Ge, S.; Velu, S.E.; Nadkarni, D.H.; et al. Experimental therapy of ovarian cancer with synthetic makaluvamine analog: In vitro and in vivo anticancer activity and molecular mechanisms of action. PLoS ONE 2011, 6, e20729. [CrossRef] [PubMed]

8. Cowan, J.; Shadab, M.; Nadkarni, D.H.; Kailash, K.C.; Velu, S.E.; Yusuf, N. Novel marine natural product derived pyrroloiminoquinone with potent activity against skin cancer cells. Mar. Drugs 2019, 17, 443. [CrossRef]

9. Radisky, D.C.; Radisky, E.S.; Barrows, L.R.; Copp, B.R.; Kramer, R.A.; Ireland, C.M. Novel cytotoxic topoisomerase II inhibiting pyrroloiminoquinones from Fijian sponges of the genus Zyzzya. J. Am. Chem. Soc. 1993, 115, 1632-1638. [CrossRef]

10. Lin, S.; McCauley, E.P.; Lorig-Roach, N.; Tenney, K.; Naphen, C.N.; Yang, A.-M.; Johnson, T.A.; Hernadez, T.; Rattan, R.; Valeriote, F.A.; et al. Another Look at pyrroloiminoquinone alkaloids-perspectives on their therapeutic potential from known structures and semisynthetic analogues. Mar. Drugs 2017, 15, 98. [CrossRef]

11. Larghi, E.L.; Bohn, M.L.; Kaufman, T.S. Aaptamine and related products. Their isolation, chemical syntheses, and biological activity. Tetrahedron 2009, 65, 4257-4282. [CrossRef]

12. Nakamura, H.; Kobayashi, J.; Ohizumi, Y.; Hirata, Y. Isolation and structure of aaptamine a novel heteroaromatic substance possessing $\alpha$-blocking activity from the sea sponge Aaptos aaptos. Tetrahedron Lett. 1982, 23, 5555-5558. [CrossRef]

13. Gul, W.; Hammond, N.L.; Yousaf, M.; Bowling, J.J.; Schinazi, R.F.; Wirtz, S.S.; Andrews, G.A.; Cuevas, C.; Hamann, M.T. Modification at the $\mathrm{C} 9$ position of the marine natural product isoaaptamine and the impact on HIV-1, mycobacterial, and tumor cell activity. Bioorg. Med. Chem. 2006, 14, 8495-8505. [CrossRef] [PubMed]

14. Pettit, G.R.; Hoffmann, H.; McNulty, J.; Higgs, K.C.; Murphy, A.; Molloy, D.J.; Herald, D.L.; Williams, M.D.; Pettit, R.K.; Doubek, D.L.; et al. Antineoplastic agents. 380. Isolation and X-ray crystal structure determination of isoaaptamine from the Republic of Singapore Hymeniacidon sp. and conversion to the phosphate prodrug hystatin 1. J. Nat. Prod. 2004, 67, 506-509. [CrossRef] [PubMed]

15. Arai, M.; Han, C.; Yamano, Y.; Setiawan, A.; Kobayashi, M. Aaptamines, marine spongean alkaloids, as anti-dormant mycobacterial substances. J. Nat. Med. 2014, 68, 372-376. [CrossRef] [PubMed]

16. Souza, T.M.L.; Abrantes, J.L.; Epifanio, R.A.; Fontes, C.F.L.; Frugulhetti, I.C.P.P. The alkaloid 4-methylaaptamine isolated from the sponge Aaptos aaptos impairs Herpes simplex virus type 1 penetration and immediate-early protein synthesis. Planta Med. 2007, 73, 200-205. [CrossRef] [PubMed]

17. Gong, K.; Miao, S.; Yang, L.; Wu, Y.; Guo, J.; Chen, W.; Dai, J.; Du, J.; Xi, S. Aaptamine attenuates the proliferation and progression of non-small cell lung carcinoma. Pharm Biol. 2020, 58, 1044-1054. [CrossRef] 
18. Jang, K.H.; Chung, S.C.; Shin, J.; Lee, S.H.; Kim, T.I.; Lee, H.S.; Oh, K.B. Aaptamines as sortase A inhibitors from the tropical sponge Aaptos aaptos. Bioorg. Med. Chem. Lett. 2007, 17, 5366-5369. [CrossRef]

19. Ioffina, D.I.; Volkovitskaya, O.E.; Gorkin, V.Z.; Rebachuk, N.M.; Utkina, N.K.; Fedoreev, S.A. Aaptamine-New selective type A monoamine-oxidase inhibitor. Pharm. Chem. J. 1990, 24, 456-458. [CrossRef]

20. Sova, V.V.; Fedoreev, S.A. Metabolites from sponges as inhibitors of $\beta-1,3$-glucanase. Chem. Nat. Compd. 1990, $26,420-422$. [CrossRef]

21. Tsukamoto, S.; Yamanokuchi, R.; Yoshitomi, M.; Sato, K.; Ikeda, T.; Rotinsulu, H.; Mangindaan, R.E.P.; de Voogd, N.J.; van Soest, R.W.M.; Yokosawa, H. Aaptamine, an alkaloid from the sponge Aaptos suberitoides, functions as a proteasome inhibitor. Bioorg. Med. Chem. Lett. 2010, 20, 3341-3343. [CrossRef]

22. Tischler, D.A. Perspective on enzyme inhibitors from marine organisms. Mar. Drugs 2020, 18, 431. [CrossRef] [PubMed]

23. Ruocco, N.; Costantini, S.; Palumbo, F.; Costantini, M. Marine sponges and bacteria as challenging sources of enzyme inhibitors for pharmacological applications. Mar. Drugs 2017, 15, 173. [CrossRef]

24. Asano, N. Glycosidase inhibitors: Update and perspectives on practical use. Glycobiology 2003, 13, 93R-104R. [CrossRef]

25. Yamamoto, N.; Urade, M. Pathogenic significance of $\alpha-\mathrm{N}$-acetylgalactosaminidase activity found in the hemagglutinin of influenza virus. Microbes Infect. 2005, 7, 674-681. [CrossRef]

26. Yamamoto, N. Pathogenic significance of $\alpha$-N-acetylgalactosaminidase activity found in the envelope glycoprotein gp 160 of human immunodeficiency virus Type, I. AIDS Res. Hum. Retroviruses 2006, 22, 262-271. [CrossRef] [PubMed]

27. Van Diggelen, O.P.; Schindler, D.; Kleijer, W.J.; Huijmans, J.M.G.; Galjaard, H.; Linden, H.-U.; Peter-Katalinic, J.; Egge, H.; Cantz, M. Lysosomal alpha-NaGalase deficiency: A new inherited metabolic disease. Lancet 1987, 2, 804. [CrossRef]

28. Bakunina, I.Y.; Balabanova, L.A.; Pennacchio, A.; Trincone, A. Hooked on $\alpha$-D-galactosidases: From biomedicine to enzymatic synthesis. Crit. Rev. Biotechnol. 2016, 36, 233-245. [CrossRef]

29. Bakunina, I.Y.; Sova, V.V.; Nedashkovskaya, O.I.; Kuhlmann, R.A.; Likhosherstov, L.M.; Martynova, M.I.; Mihailov, V.V.; Elyakova, L.A. $\alpha$-D-galactosidase of the marine bacterium Pseudoalteromonas sp. KMM 701. Biochemisrty 1998, 63, $1209-1215$.

30. Balabanova, L.A.; Bakunina, I.Y.; Nedashkovskaya, O.I.; Makarenkova, I.D.; Zaporozhets, T.S.; Besednova, N.N.; Zvyagintseva, T.N.; Rasskazov, V.A. Molecular characterization and therapeutic potential of a marine bacterium Pseudoalteromonas sp. KMM 701 $\alpha$-D-galactosidase. Mar. Biotechnol. 2010, 12, 111-120. [CrossRef]

31. Balabanova, L.; Shkryl, Y.; Slepchenko, L.; Cheraneva, D.; Podvolotskaya, A.; Bakunina, I.; Nedashkovskaya, O.; Son, O.; Tekutyeva, L. Genomic features of a food-derived Pseudomonas aeruginosa strain PAEM and biofilm-associated gene expression under a marine bacterial $\alpha$-galactosidase. Int. J. Mol. Sci. 2020, 21, 7666. [CrossRef]

32. Yamamoto, N.; Naraparaju, V.R.; Asbell, S.O. Deglycosylation of serum vitamin D3-binding protein leads to immunosuppression in cancer patients. Cancer Res. 1996, 56, 2827-2831. [CrossRef] [PubMed]

33. Saburi, E.; Tavakol-Afshari, J.; Biglari, S.; Mortazavi, Y. Is $\alpha$-N-acetylgalactosaminidase the key to curing cancer? A mini-review and hypothesis. JBUON 2017, 22, 1372-1377. [PubMed]

34. Albracht, S.P.J.; van Pelt, J. Multiple exo-glycosidases in human serum as detected with the substrate DNP- $\alpha$-GalNAc. II. Three $\alpha-\mathrm{N}$-acetylgalactosaminidase-like activities in the $\mathrm{pH} 5$ to 8 region. BBA Clin. 2017, 8, 90-96. [CrossRef] [PubMed]

35. Ayers, B.J.; Hollinshead, J.; Saville, A.W.; Nakagawa, S.; Adachi, I.; Kato, A.; Izumori, K.; Bartholomew, B.; Fleet, G.W.J.; Nash, R.J. Iteamine, the first alkaloid isolated from Itea virginica L. inflorescence. Phytochemistry 2014, 100, 126-131. [CrossRef] [PubMed]

36. Clark, N.E.; Metcalf, M.C.; Best, D.; Fleet, G.W.J.; Garman, S.C. Pharmacological chaperones for human $\alpha-N$-acetylgalactosaminidase. Proc. Nalt. Acad. Sci. USA 2012, 109, 17400-17405. [CrossRef]

37. Bakunina, I.Y.; Chadova, O.A.; Malyarenko, O.S.; Ermakova, S.P. The Effect of fucoidan from the brown alga Fucus evanescence on the activity of $\alpha-\mathrm{N}$-acetylgalactosaminidase of human colon carcinoma cells. Mar. Drugs 2018, 16, 155. [CrossRef] [PubMed]

38. Bakunina, I.Y.; Kol'tsova, E.A.; Pokhilo, N.D.; Shestak, O.P.; Yakubovskaya, A.Y.; Zvyagintseva, T.N.; Anufriev, V.F. Effect of 5-hydroxy- and 5,8-dihydroxy-1,4-naphthoquinones on the hydrolytic activity of alpha-galactosidase. Chem. Nat. Comp. 2009, 45, 69-73. [CrossRef]

39. Utkina, N.K.; Likhatskaya, G.N.; Balabanova, L.A.; Bakunina, I.Y. Sponge-derived polybrominated diphenyl ethers and dibenzop-dioxins, irreversible inhibitors of the bacterial $\alpha$-D-galactosidase. Environ. Sci. Processes Impacts 2019, 21, 1754-1763. [CrossRef]

40. Bakunina, I.; Likhatskaya, G.; Slepchenko, L.; Balabanova, L.; Tekutyeva, L.; Son, O.; Shubina, L.; Makarieva, T. Effect of pentacyclic guanidine alkaloids from the sponge Monanchora pulchra on activity of $\alpha$-glycosidases from marine bacteria. Mar. Drugs 2019, 17, 22. [CrossRef]

41. Nakamura, H.; Kobayashi, J.; Ohizumi, Y.; Hirata, Y. Aaptamines. Novel benzo[de] [I,6] naphthyridines from the Okinawan marine sponge Aaptos aaptos. J. Chem. Soc. Perkin Trans. I 1987, 173-176. [CrossRef]

42. Utkina, N.K.; Denisenko, V.A.; Pushilin, M.A. Aaptanone, a novel zwitterionic metabolite of the aaptamine class with an oxygenated 1,6-naphthyridine core from the Vietnamese marine sponge Aaptos aaptos. Tetrahedron Lett. 2009, 50, $2580-2582$. [CrossRef]

43. Stierle, D.B.; Faulkner, D.J. Two new pyrroloquinoline alkaloids from the sponge Damiria sp. J. Nat. Prod. 1991, 54, 1131-1133. [CrossRef]

44. Schmidt, E.W.; Harper, M.K.; Faulkner, D.J. Makaluvamines H-M and damirone C from the pohnpeian sponge Zyzzya fuliginosa. J. Nat. Prod. 1995, 58, 1861-1867. [CrossRef] [PubMed] 
45. Carney, J.R.; Scheuer, P.J.; Kelly-Borges, M. Makaluvamine G, a cytotoxic pigment from an Indonesian sponge Histodermella sp. Tetrahedron 1993, 49, 8483-8486. [CrossRef]

46. Utkina, N.R.; Makarchenko, A.E.; Denisenko, V.A.; Dmitrenok, P.S. Zyzzyanone A, a novel pyrrolo[3,2-f]indole alkaloid from the Australian marine sponge Zyzzya fuliginosa. Tetrahedron Lett. 2004, 45, 7491-7494. [CrossRef]

47. Laemmli, V.K. Cleavage of structural proteins during of the head of bacteriophage T4. Nature 1970, 227, 680-685. [CrossRef]

48. Golotin, V.A.; Balabanova, L.A.; Noskova, Y.A.; Slepchenko, L.A.; Bakunina, I.Y.; Vorobieva, N.S.; Terentieva, N.A.; Rasskazov, V.A. Optimization of cold-adapted $\alpha$-D-galactosidase expression in Escherichia coli. Protein Expr. Purif. 2016, 123, 14-18. [CrossRef]

49. Bakunina, I.Y.; Balabanova, L.A.; Golotin, V.A.; Slepchenko, L.A.; Isakov, V.V.; Rasskazov, V.V. Stereochemical course of hydrolytic reaction catalyzed by alpha-galactosidase from cold adaptable marine bacterium of genus Pseudoalteromonas. Front. Chem./Chem. Biol. 2014, 2, 1-6. [CrossRef]

50. Bradford, M.M. A rapid and sensitive method for the quantitation of microgram quantities of protein utilizing the principle of protein-dye binding. Anal. Biochem. 1976, 72, 248-254. [CrossRef]

51. Varfolomeev, S.D. Khimicheskaya Enzimologiya (Chemical Enzymology); Akademiya: Moscow, Russia, $2005 ;$ p. 472.

52. Dubrovskaya, Y.V.; Makarieva, T.N.; Shubina, L.K.; Bakunina, I.Y. Effect of pentacyclic guanidine alkaloids from the marine sponge Monanchora pulchra Lambe, 1894 on activity of natural $\beta-1,3-\mathrm{D}$-glucanase from the marine fungus Chaetomium indicum Corda, 1840 and the marine bivalve mollusk Spisula sachalinensis, Schrenck, 1861. Rus. J. Mar. Biol. 2018, 44, 127-134. [CrossRef]

53. Parsons, Z.D.; Gates, K.S. Redox regulation of protein tyrosine phosphatases: Methods for kinetic analysis of covalent enzyme inactivation. Methods Enzymol. 2013, 528, 129-154. [CrossRef] [PubMed]

54. Bakunina, I.; Slepchenko, L.; Anastyuk, S.; Isakov, V.; Likhatskaya, G.; Kim, N.; Tekutyeva, L.; Son, O.; Balabanova, L. Characterization of properties and transglycosylation abilities of recombinant $\alpha$-galactosidase from cold adapted marine bacterium Pseudoalteromonas KMM 701 and its C494N, D451A mutants. Mar. Drugs 2018, 16, 349. [CrossRef] [PubMed]

55. Fredslund, F.; Hachem, M.A.; Larsen, R.J.; Sørensen, P.G.; Coutinho, P.M.; Lo Leggio, L.; Svensson, B. Crystal structure of $\alpha$-galactosidase from Lactobacillus acidophilus NCFM: Insight into tetramer formation and substrate binding. J. Mol Biol. 2011, 412, 466-480. [CrossRef] [PubMed] 